\title{
Thalassobius maritimus sp. nov., isolated from seawater
}

\author{
Correspondence \\ Jung-Hoon Yoon \\ jhyoon69@skku.edu
}

\author{
Sooyeon Park, ${ }^{1}$ Mi-Hwa Lee, ${ }^{1}$ Jung-Sook Lee, ${ }^{1}$ Tae-Kwang Oh ${ }^{1}$ \\ and Jung-Hoon Yoon ${ }^{1,2}$ \\ ${ }^{1}$ Korea Research Institute of Bioscience and Biotechnology (KRIBB), PO Box 115, Yusong, \\ Taejon, South Korea \\ ${ }^{2}$ Department of Food Science and Biotechnology, Sungkyunkwan University, Jangan-gu, \\ Suwon, South Korea
}

\begin{abstract}
A Gram-stain-negative, aerobic, motile, rod-shaped bacterial strain, GSW-M6 ${ }^{\top}$, was isolated from seawater of Geoje island, Korea, and was subjected to a polyphasic taxonomic study. Strain GSW-M6 ${ }^{\top}$ grew optimally at $\mathrm{pH} 7.0-8.0$, at $30{ }^{\circ} \mathrm{C}$ and in the presence of $2 \%(\mathrm{w} / \mathrm{v}) \mathrm{NaCl}$. In the neighbour-joining phylogenetic tree based on $16 \mathrm{~S}$ rRNA gene sequences, strain GSW-M6 ${ }^{\top}$ clustered with Thalassobius aestuarii, Thalassobius gelatinovorus and Thalassobius mediterraneus. Strain GSW-M6 ${ }^{\top}$ exhibited 96.2-96.9\% $16 \mathrm{~S}$ rRNA gene sequence similarity to the type strains of these three Thalassobius species. Strain GSW-M6 ${ }^{\top}$ contained Q-10 as the predominant ubiquinone and $\mathrm{C}_{18: 1} \omega 7 \mathrm{c}$ as the major fatty acid. The polar lipid profiles of strain GSW-M6 ${ }^{\top}$ and the type strains of the three Thalassobius species were similar, with phosphatidylcholine, phosphatidylglycerol, phosphatidylethanolamine and an unidentified lipid as common major components. The DNA G $+\mathrm{C}$ content of strain GSW-M6 ${ }^{\top}$ was 57 mol\%. The mean level of DNA-DNA relatedness between strain $\mathrm{GSW}-\mathrm{M6}^{\top}$ and the type strain of Thalassobius gelatinovorus was $17 \%$. Differential phenotypic properties, together with the phylogenetic and genetic distinctiveness, enabled strain $\mathrm{GSW}-\mathrm{M} 6^{\top}$ to be differentiated from recognized species of the genus Thalassobius. On the basis of the data presented, strain GSW-M6 ${ }^{\top}$ is considered to represent a novel species of the genus Thalassobius, for which the name Thalassobius maritimus sp. nov. is proposed. The type strain is GSW-M6 ${ }^{\top}$ $\left(=\right.$ KCTC $23347^{\top}=$ CCUG $\left.60021^{\top}\right)$.
\end{abstract}

The genus Thalassobius was first proposed by Arahal et al. (2005) based on the description of a novel species, Thalassobius mediterraneus (the type species), and the reclassification of Ruegeria gelatinovorans (Uchino et al., 1998) as Thalassobius gelatinovorus. Subsequently, a third species of the genus was described, Thalassobius aestuarii (Yi \& Chun, 2006). Phylogenetically, the genus Thalassobius forms an evolutionary lineage within the Alphaproteobacteria (Arahal et al., 2005; Lee et al., 2005). In this study, we report the taxonomic characterization of a Thalassobius-like bacterial strain, GSW-M6 ${ }^{\mathrm{T}}$, which was isolated from seawater of the South Sea of Korea. The aim of the present work was to determine the exact taxonomic position of strain GSW-M6 ${ }^{\mathrm{T}}$ by using a polyphasic characterization that included determination of phenotypic properties and a detailed phylogenetic investigation based on 16S rRNA gene sequences.

Strain GSW-M6 ${ }^{\mathrm{T}}$ was isolated by the dilution plating technique on marine agar 2216 (MA; Difco) at $25{ }^{\circ} \mathrm{C}$. The

The GenBank/EMBL/DDBJ accession number for the 16S rRNA gene sequence of strain GSW-M6 ${ }^{\top}$ is $\mathrm{HM} 748766$. type strains of the three recognized Thalassobius species were used as reference strains for phenotypic characterization, including analyses of polar lipids and fatty acids, and DNA-DNA hybridization experiments. T. aestuarii KCTC $12049^{\mathrm{T}}$ and T. gelatinovorus KCTC $22092^{\mathrm{T}}$ were obtained from the Korean Collection for Type Cultures, Taejon, Republic of Korea, and T. mediterraneus CCUG $49438^{\mathrm{T}}$ was obtained from the Culture Collection of the University of Göteborg, Göteborg, Sweden. Cell morphology was examined by using light microscopy (E600; Nikon) and transmission electron microscopy (CM-20; Philips). Flagellation was determined by using transmission electron microscopy on cells from an exponentially growing culture. For this, cells were negatively stained with $1 \%(\mathrm{w} / \mathrm{v})$ phosphotungstic acid and the grids were examined after being air-dried. The Gram reaction was determined by using the bioMérieux Gram stain kit according to the manufacturer's instructions. The morphological, physiological and biochemical characteristics of strain GSW-M6 ${ }^{\mathrm{T}}$ were investigated by using routine cultivation on MA at $30{ }^{\circ} \mathrm{C}$. Growth at $4,10,20,25,30,37,40$ and $45{ }^{\circ} \mathrm{C}$ was 
measured on MA. Growth in the absence of $\mathrm{NaCl}$ and at $0.5 \%$ and $1.0-10.0 \%(\mathrm{w} / \mathrm{v}) \mathrm{NaCl}$ (in increments of $1.0 \%$ ) was investigated in trypticase soy broth (TSB) prepared according to the formula of the Difco medium except that $\mathrm{NaCl}$ was excluded. The requirement for $\mathrm{Mg}^{2+}$ was tested by using TSB in the presence and absence of $0.45 \%(\mathrm{w} / \mathrm{v})$ $\mathrm{MgCl}_{2} \cdot 6 \mathrm{H}_{2} \mathrm{O}$. The $\mathrm{pH}$ range for growth was determined in marine broth (MB) adjusted to $\mathrm{pH}$ 4.5-10.5 (increments of $0.5 \mathrm{pH}$ units) by the addition of $\mathrm{HCl}$ or $\mathrm{Na}_{2} \mathrm{CO}_{3}$. Growth under anaerobic conditions was determined after incubation in a Forma anaerobic chamber on MA and on MA supplemented with $0.1 \%(\mathrm{w} / \mathrm{v})$ potassium nitrate, both of which had been prepared anaerobically under a nitrogen atmosphere. Catalase and oxidase activities were determined as described by Cowan \& Steel (1965). Hydrolysis of casein, hypoxanthine, starch, tyrosine, Tweens 20, 40, 60 and 80 and xanthine was tested on MA by using the substrate concentrations described by Cowan \& Steel (1965). Nitrate reduction and hydrolysis of aesculin, gelatin and urea were investigated as described by Lányí (1987), with the modification that artificial seawater was used in preparation of the media. The artificial seawater contained (per litre distilled water) $23.6 \mathrm{~g} \mathrm{NaCl}, 0.64 \mathrm{~g}$ $\mathrm{KCl}, 4.53 \mathrm{~g} \mathrm{MgCl}_{2} .6 \mathrm{H}_{2} \mathrm{O}, 5.94 \mathrm{~g} \mathrm{MgSO}_{4} .7 \mathrm{H}_{2} \mathrm{O}$ and $1.3 \mathrm{~g}$ $\mathrm{CaCl}_{2} \cdot 2 \mathrm{H}_{2} \mathrm{O}$ (Bruns et al., 2001). Acid production from carbohydrates was determined as described by Leifson (1963). Utilization of substrates as sole carbon and energy sources was tested as described by Baumann \& Baumann (1981), by using supplementation with $2 \%(\mathrm{v} / \mathrm{v})$ Hutner's mineral base (Cohen-Bazire et al., 1957) and $1 \%(\mathrm{v} / \mathrm{v})$ vitamin solution (Staley, 1968). $\mathrm{H}_{2} \mathrm{~S}$ production was tested as described by Bruns et al. (2001). Susceptibility to antibiotics was investigated on MA plates by using antibiotic discs (Advantec) containing the following: polymyxin $\mathrm{B}, 100 \mathrm{U}$; streptomycin, $50 \mu \mathrm{g}$; penicillin $\mathrm{G}$, $20 \mathrm{U}$; chloramphenicol, $100 \mu \mathrm{g}$; ampicillin, $10 \mu \mathrm{g}$; cephalothin, $30 \mu \mathrm{g}$; gentamicin, $30 \mu \mathrm{g}$; novobiocin, $5 \mu \mathrm{g}$; tetracycline, $30 \mu \mathrm{g}$; kanamycin, $30 \mu \mathrm{g}$; lincomycin, $15 \mu \mathrm{g}$; oleandomycin, $15 \mu \mathrm{g}$; neomycin, $30 \mu \mathrm{g}$; and carbenicillin, $100 \mu \mathrm{g}$. Enzyme activities were determined, after incubation for $4 \mathrm{~h}$ at $30{ }^{\circ} \mathrm{C}$, by using the API ZYM system (bioMérieux). Other physiological and biochemical tests were performed with the API 20E system (bioMérieux) according to the manufacturer's instructions.

Chromosomal DNA was extracted and purified according to the procedure described by Yoon et al. (1996), with the modification that RNase $\mathrm{T} 1$ was used in combination with RNase A to minimize contamination by RNA. Amplification of the $16 \mathrm{~S}$ rRNA gene was performed by using two universal primers as described previously (Yoon et al., 1998) and the PCR products were purified by using a QIAquick PCR purification kit (Qiagen). Sequencing of the amplified 16S rRNA gene and phylogenetic analysis were performed as described by Yoon et al. (2003). Isoprenoid quinones were analysed according to Komagata \& Suzuki (1987), by using reversed-phase HPLC and a YMC ODS-A $(250 \times 4.6 \mathrm{~mm})$ column. For cellular fatty acid analysis, cell mass of strain GSW-M6 ${ }^{\mathrm{T}}$ and the three reference strains was harvested from MA plates after cultivation for 4 days at $30{ }^{\circ} \mathrm{C}$. The fatty acids were extracted and fatty acid methyl esters were prepared according to the standard protocol of the MIDI/Hewlett Packard Microbial Identification System (Sasser, 1990). Polar lipids were extracted according to the procedures described by Minnikin et al. (1984) and were identified by two-dimensional TLC followed by spraying with appropriate detection reagents (Minnikin et al., 1984; Komagata \& Suzuki, 1987). The presence of phosphatidylcholine was identified by spraying with Dragendorff's reagent. The DNA G $+\mathrm{C}$ content was determined according to the method of Tamaoka \& Komagata (1984) with the modification that DNA was hydrolysed with nuclease P1 (Sigma) and the resultant nucleotides were analysed by reversed-phase HPLC. DNADNA hybridization was performed fluorometrically according to the method of Ezaki et al. (1989) by using photobiotin-labelled DNA probes and microdilution wells. Hybridization was performed with five replications for each sample. The highest and lowest values obtained for each sample were excluded, and the means of the remaining three values were quoted as DNA-DNA relatedness values.

The morphological, cultural, physiological and biochemical characteristics of strain GSW-M6 ${ }^{\mathrm{T}}$ are given in the species description and in Table 1. Strain GSW-M6 ${ }^{\mathrm{T}}$ did not grow in TSB without $\mathrm{MgCl}_{2}$, indicating that $\mathrm{Mg}^{2+}$ ions are required for growth. Strain GSW-M6 ${ }^{\mathrm{T}}$ could be differentiated from recognized Thalassobius species based on differences in phenotypic properties, including motility, temperature range for growth, hydrolysis of several substrates and nitrate reduction, as shown in Table 1 . The almost-complete $16 \mathrm{~S}$ rRNA gene sequence of strain GSW-M6 ${ }^{\mathrm{T}}$, comprising $1384 \mathrm{nt}$ (approx. 96\% of the Escherichia coli 16S rRNA gene sequence), was determined in this study. Comparative $16 \mathrm{~S}$ rRNA gene sequence analysis showed that strain GSW$\mathrm{M}^{\mathrm{T}}$ was phylogenetically most closely related to the genus Thalassobius. In the phylogenetic tree reconstructed with the neighbour-joining algorithm, strain GSW-M6 ${ }^{\mathrm{T}}$ joined the cluster comprising Thalassobius species (Fig. 1). The phylogenetic affiliation of strain GSW-M6 ${ }^{\mathrm{T}}$ to members of the genus Thalassobius was also maintained in the tree based on the maximum-likelihood algorithm. Strain GSW-M6 ${ }^{\mathrm{T}}$ exhibited 16S rRNA gene sequence similarity of 96.2, 96.6 and $96.9 \%$ to the type strains of $T$. mediterraneus, $T$. aestuarii and T. gelatinovorus, respectively.

The chemotaxonomic properties of strain GSW-M6 ${ }^{\mathrm{T}}$ confirmed the result of phylogenetic analysis, namely that strain GSW-M $6^{\mathrm{T}}$ is affiliated to the genus Thalassobius. The predominant isoprenoid quinone detected in strain GSW$\mathrm{M}^{\mathrm{T}}$ was ubiquinone-10 (Q-10), consistent with data for Thalassobius species (Uchino et al., 1998; Yi \& Chun, 2006). The only major fatty acid ( $>10 \%$ of the total) found in strain GSW-M6 ${ }^{\mathrm{T}}$ was $\mathrm{C}_{18: 1} \omega 7 c(71.8 \%)$. The fatty acid profiles of strain GSW-M6 ${ }^{\mathrm{T}}$ and the type strains of the three recognized Thalassobius species were similar, 
Table 1. Differential phenotypic characteristics between strain GSW-M6 ${ }^{\top}$ and type strains of Thalassobius species

Strains: 1, GSW-M6 ${ }^{\mathrm{T}}$; 2, T. aestuarii KCTC $12049^{\mathrm{T}}$; 3, T. gelatinovorus KCTC $22092^{\mathrm{T}}$; 4, T. mediterraneus CCUG $49438^{\mathrm{T}}$. Data are from the present study except those for Gram staining, motility, temperature range for growth, nitrate reduction, hydrolysis of gelatin and DNA G $+\mathrm{C}$ content of the reference strains, which are from Arahal et al. (2005) and Yi \& Chun (2006). All strains are Gram-stain-negative. All are positive for catalase and oxidase activities, utilization of acetate, pyruvate, succinate and L-malate and susceptibility to ampicillin, carbenicillin, cephalothin, chloramphenicol, gentamicin, kanamycin, neomycin, novobiocin, oleandomycin, penicillin G, streptomycin and tetracycline. All strains are negative for production of indole ${ }^{\star}$ and $\mathrm{H}_{2} \mathrm{~S}^{\star}$, activities of arginine dihydrolase $^{\star}$, lysine decarboxylase $e^{\star}$, ornithine decarboxylase ${ }^{\star}$ and tryptophan deaminase ${ }^{\star}$, hydrolysis of aesculin, starch, Tween 60 and xanthine, utilization of D-galactose, trehalose, L-arabinose, sucrose, maltose, benzoate, formate and L-glutamate, acid production from cellobiose, D-fructose, D-galactose, D-glucose, myoinositol, lactose, maltose, D-mannitol, D-mannose, melezitose, melibiose, raffinose, L-rhamnose, D-sorbitol, sucrose, trehalose and D-xylose and susceptibility to lincomycin. All strains contain phosphatidylcholine, phosphatidylethanolamine and phosphatidylglycerol. w, Weakly positive.

\begin{tabular}{|c|c|c|c|c|}
\hline Characteristic & 1 & 2 & 3 & 4 \\
\hline Motility & + & - & + & - \\
\hline Temperature range for growth $\left({ }^{\circ} \mathrm{C}\right)$ & $10-37$ & $15-35$ & $4-37$ & $13-37$ \\
\hline Nitrate reduction & + & - & + & - \\
\hline \multicolumn{5}{|l|}{ Hydrolysis of: } \\
\hline Casein & + & - & - & - \\
\hline Gelatin & - & + & + & - \\
\hline Hypoxanthine & + & + & + & - \\
\hline Tween 20 & - & + & + & + \\
\hline Tween 40 & - & + & - & - \\
\hline Tween 80 & - & $\mathrm{W}$ & - & - \\
\hline Tyrosine & + & + & + & - \\
\hline Urea & - & - & + & - \\
\hline \multicolumn{5}{|l|}{ Utilization of: } \\
\hline Cellobiose & + & - & - & - \\
\hline D-Fructose & + & - & - & + \\
\hline D-Glucose & + & + & - & + \\
\hline D-Mannose & + & - & - & - \\
\hline D-Xylose & - & + & - & - \\
\hline Citrate & + & + & - & + \\
\hline Salicin & + & - & - & - \\
\hline \multicolumn{5}{|l|}{ Acid production from: } \\
\hline L-Arabinose & + & - & - & - \\
\hline D-Ribose & - & + & - & - \\
\hline Susceptibility to polymyxin B & + & - & - & - \\
\hline Additional major polar lipid(s) $\dagger$ & $\mathrm{L}$ & AL, Ls & Ls & $\mathrm{L}$ \\
\hline DNA G $+\mathrm{C}$ content $(\mathrm{mol} \%)$ & 57 & 61 & 59 & 57 \\
\hline
\end{tabular}

${ }^{*}$ Data obtained using the API $20 \mathrm{E}$ system.

$\dagger$ AL, Unidentified aminolipid; L(s), unidentified lipid(s).

although there were differences in the proportions of some components (Table 2). Major polar lipids found in strain GSW-M6 ${ }^{\mathrm{T}}$ were phosphatidylcholine, phosphatidylglycerol, phosphatidylethanolamine and an unidentified lipid (Fig. 2, Table 1), a profile that was similar to those of the type strains of the three Thalassobius species. However, the polar lipid profile of strain GSW-M6 ${ }^{\mathrm{T}}$ was distinguishable from those of T. aestuarii KCTC $12049^{\mathrm{T}}$ and T. gelatinovorus KCTC $22092^{\mathrm{T}}$ in that an additional unidentified lipid and/or an amino lipid were also present (Fig. 2, Table 1). The DNA G + C content of strain GSW-M6 ${ }^{\mathrm{T}}$ was $57 \mathrm{~mol} \%$.

Strain GSW-M6 ${ }^{\mathrm{T}}$ could be distinguished from recognized Thalassobius species based on differences in several phenotypic characteristics, most of which were determined under the same conditions and methods (Table 1). The mean level of DNA-DNA relatedness between strain GSW$\mathrm{M6}^{\mathrm{T}}$ and T. gelatinovorus KCTC $22092^{\mathrm{T}}$ was $17 \%$. The 


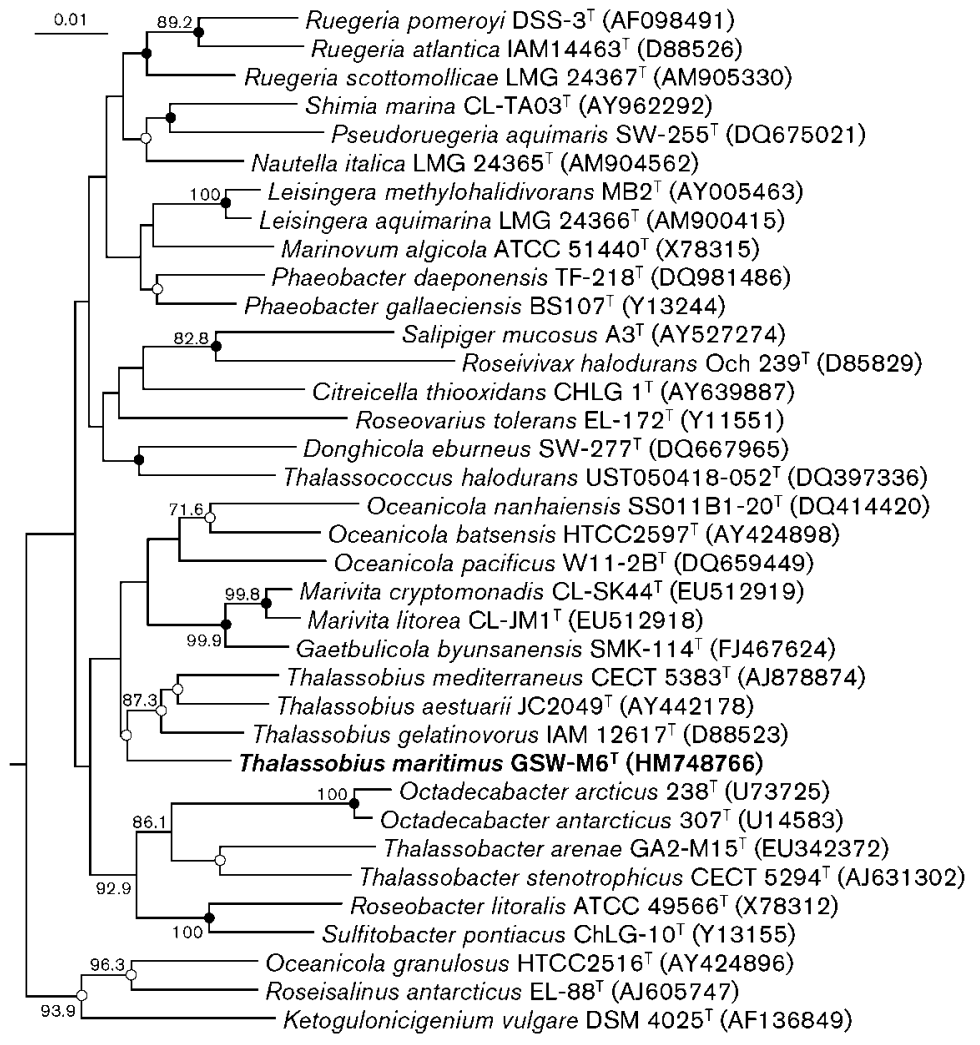

Fig. 1. Neighbour-joining phylogenetic tree based on 16S rRNA gene sequences showing the positions of strain GSW-M6 ${ }^{\top}$, the type strains of Thalassobius species and some other related taxa. Bootstrap values (expressed as percentages of 1000 replications) $>50 \%$ are shown at branch points. Filled circles indicate that the corresponding nodes were also recovered in trees generated with the maximum-likelihood and maximum-parsimony algorithms. Open circles indicate that the corresponding nodes were also recovered in the tree generated with one of these algorithms. The sequence of Stappia stellulata IAM $12621^{\top}$ (GenBank accession no. D88525) was used as an outgroup (not shown). Bar, 0.01 substitutions per nucleotide position.

phylogenetic distinctiveness of strain GSW-M $6^{\mathrm{T}}$, together with differential phenotypic properties and genetic distinctiveness, shows that this strain is separate from recognized Thalassobius species (Wayne et al., 1987; Stackebrandt \& Goebel, 1994; Tindall et al., 2010). Therefore, on the basis

Table 2. Cellular fatty acid compositions of strain GSW-M6 ${ }^{\top}$ and the type strains of recognized Thalassobius species

Strains: 1, GSW-M6 ${ }^{\mathrm{T}} ; 2$, T. aestuarii KCTC $12049^{\mathrm{T}} ; 3$, T. gelatinovorus KCTC $22092^{\mathrm{T}}$; 4, T. mediterraneus CCUG $49438^{\mathrm{T}}$. All data are from the present study. Values are percentages of total fatty acids; fatty acids that represented $<1.0 \%$ in all strains were omitted. - , Not detected; ECL, equivalent chain-length.

\begin{tabular}{|lllll|}
\hline Fatty acid & $\mathbf{1}$ & $\mathbf{2}$ & $\mathbf{3}$ & $\mathbf{4}$ \\
\hline Straight-chain & & & & \\
$\quad \mathrm{C}_{16: 0}$ & 8.6 & 4.6 & 12.2 & 8.8 \\
$\mathrm{C}_{17: 0}$ & 1.9 & 0.6 & 1.0 & 0.6 \\
$\mathrm{C}_{18: 0}$ & 3.7 & 2.3 & 1.7 & 3.0 \\
Unsaturated & & & & \\
$\quad \mathrm{C}_{18: 1} \omega 7 c$ & 71.8 & 75.1 & 68.2 & 78.6 \\
Hydroxy & & & & \\
$\mathrm{C}_{10: 0}$ 3-OH & 4.4 & 2.1 & - & - \\
$\mathrm{C}_{12: 1}$ 3-OH & 1.2 & - & 3.8 & - \\
$\mathrm{C}_{16: 0} 2-\mathrm{OH}$ & - & 3.9 & 2.0 & - \\
11-Methyl C $18: 1 \omega 7 c$ & 2.7 & 7.3 & 6.3 & 4.7 \\
Unknown ECL 11.799 & 2.8 & 2.1 & 2.5 & - \\
\hline
\end{tabular}

of the phenotypic, chemotaxonomic and phylogenetic data presented here, strain GSW-M $6^{\mathrm{T}}$ is considered to represent a novel species of the genus Thalassobius, for which the name Thalassobius maritimus sp. nov. is proposed.

\section{Description of Thalassobius maritimus sp. nov.}

Thalassobius maritimus (ma.ri'ti.mus. L. masc. adj. maritimus of the sea, referring to the marine environment).

Cells are Gram-stain-negative, aerobic rods, $0.4-0.8 \mu \mathrm{m}$ in diameter and 1.0-6.0 $\mu \mathrm{m}$ long. Motile by means of a single polar flagellum. Colonies on MA are convex, opaque, circular with entire margins and cream-coloured after incubation for 3 days at $30{ }^{\circ} \mathrm{C}$. Growth does not occur under anaerobic conditions on MA or on MA supplemented with nitrate. Optimal growth temperature is $30{ }^{\circ} \mathrm{C}$; growth occurs at 10 and $37{ }^{\circ} \mathrm{C}$ but not at 4 or $40{ }^{\circ} \mathrm{C}$. Optimal growth at $\mathrm{pH} 7.0-8.0$; growth occurs at $\mathrm{pH} 6.0$ but not at $\mathrm{pH}$ 5.5. Optimal growth occurs in the presence of approx. $2.0 \%(\mathrm{w} / \mathrm{v}) \mathrm{NaCl}$; growth occurs in the presence of $0-7.0 \%$ $(\mathrm{w} / \mathrm{v}) \mathrm{NaCl} \mathrm{Mg}^{2+}$ ions are required for growth. In assays with the API ZYM system, positive for alkaline phosphatase and leucine arylamidase activities, weakly positive for esterase lipase (C8), but negative for acid phosphatase, cystine arylamidase, esterase (C4), lipase (C14), naphthol-AS-BI-phosphohydrolase, $N$-acetyl- $\beta$-glucosaminidase, trypsin, valine arylamidase, $\alpha$-chymotrypsin, $\alpha$-fucosidase, $\alpha$ galactosidase, $\alpha$-glucosidase, $\alpha$-mannosidase, $\beta$-galactosidase, $\beta$-glucosidase and $\beta$-glucuronidase activities. The predominant ubiquinone is Q-10. The major polar lipids are 


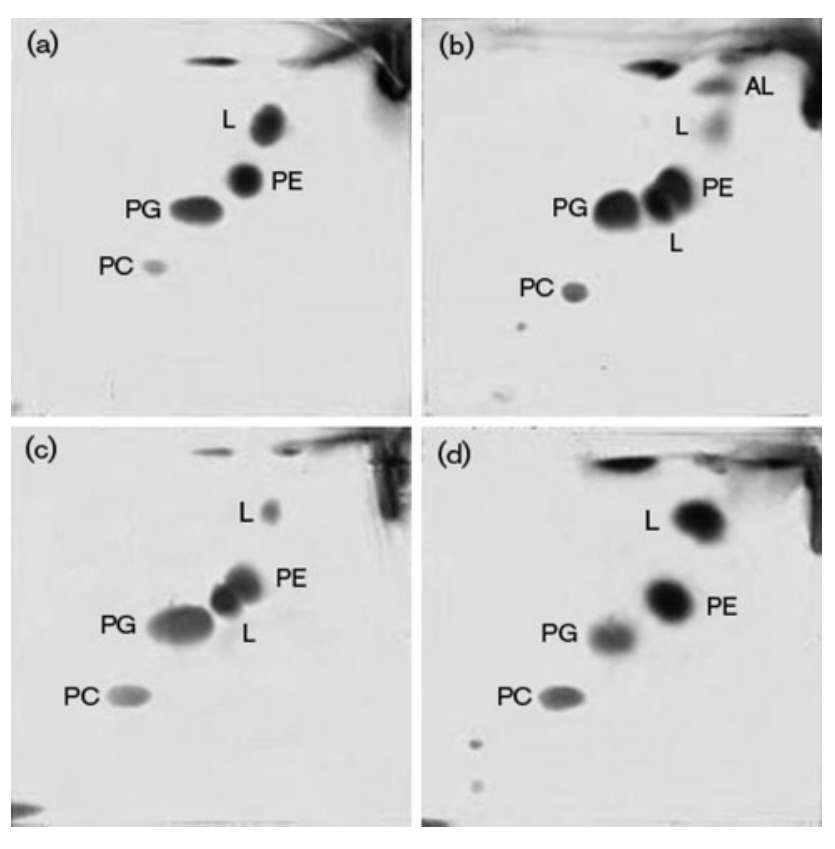

Fig. 2. TLC chromatograms of polar lipids of strain GSW-M6 ${ }^{\top}$ (a), T. aestuarii KCTC $12049^{\top}$ (b), T. gelatinovorus KCTC $22092^{\top}$ (c) and $T$. mediterraneus CCUG $49438^{\top}$ (d). PC, Phosphatidylcholine; PE, phosphatidylethanolamine; PG, phosphatidylglycerol; $A L$, unidentified aminolipid; $L$, unidentified lipid.

phosphatidylcholine, phosphatidylglycerol, phosphatidylethanolamine and an unidentified lipid. The major cellular fatty acid ( $>10 \%$ of the total) is $\mathrm{C}_{18: 1} \omega 7 c$. The DNA G+C content of the type strain is $57 \mathrm{~mol} \%$ (determined by HPLC). Other phenotypic characteristics are given in Table 1.

The type strain, GSW-M6 ${ }^{\mathrm{T}}$ (=KCTC $23347^{\mathrm{T}}=\mathrm{CCUG}$ $60021^{\mathrm{T}}$ ), was isolated from seawater of Geoje island, Korea.

\section{Acknowledgements}

This work was supported by the 21C Frontier Program of Microbial Genomics and Applications (grant MG05-0401-2-0) from the Ministry of Education, Science and Technology (MEST) of the Republic of Korea.

\section{References}

Arahal, D. R., Macián, M. C., Garay, E. \& Pujalte, M. J. (2005). Thalassobius mediterraneus gen. nov., sp. nov., and reclassification of Ruegeria gelatinovorans as Thalassobius gelatinovorus comb. nov. Int J Syst Evol Microbiol 55, 2371-2376.

Baumann, P. \& Baumann, L. (1981). The marine Gram-negative eubacteria: genera Photobacterium, Beneckea, Alteromonas, Pseudomonas, and Alcaligenes. In The Prokaryotes, pp. 1302-1331. Edited by M. P. Starr, H. Stolp, H. G. Trüper, A. Balows \& H. G. Schlegel. Berlin: Springer.

Bruns, A., Rohde, M. \& Berthe-Corti, L. (2001). Muricauda ruestringensis gen. nov., sp. nov., a facultatively anaerobic, appendaged bacterium from German North Sea intertidal sediment. Int J Syst Evol Microbiol 51, 1997-2006.
Cohen-Bazire, G., Sistrom, W. R. \& Stanier, R. Y. (1957). Kinetic studies of pigment synthesis by nonsulfur purple bacteria. J Cell Comp Physiol 49, 25-68.

Cowan, S. T. \& Steel, K. J. (1965). Manual for the Identification of Medical Bacteria. London: Cambridge University Press.

Ezaki, T., Hashimoto, Y. \& Yabuuchi, E. (1989). Fluorometric deoxyribonucleic acid-deoxyribonucleic acid hybridization in microdilution wells as an alternative to membrane filter hybridization in which radioisotopes are used to determine genetic relatedness among bacterial strains. Int J Syst Bacteriol 39, 224-229.

Komagata, K. \& Suzuki, K. (1987). Lipid and cell wall analysis in bacterial systematics. Methods Microbiol 19, 161-207.

Lányí, B. (1987). Classical and rapid identification methods for medically important bacteria. Methods Microbiol 19, 1-67.

Lee, K.-B., Liu, C.-T., Anzai, Y., Kim, H., Aono, T. \& Oyaizu, H. (2005). The hierarchical system of the 'Alphaproteobacteria': description of Hyphomonadaceae fam. nov., Xanthobacteraceae fam. nov. and Erythrobacteraceae fam. nov. Int J Syst Evol Microbiol 55, 1907-1919.

Leifson, E. (1963). Determination of carbohydrate metabolism of marine bacteria. J Bacteriol 85, 1183-1184.

Minnikin, D. E., O’Donnell, A. G., Goodfellow, M., Alderson, G., Athalye, M., Schaal, A. \& Parlett, J. H. (1984). An integrated procedure for the extraction of bacterial isoprenoid quinones and polar lipids. J Microbiol Methods 2, 233-241.

Sasser, M. (1990). Identification of bacteria by gas chromatography of cellular fatty acids, MIDI Technical Note 101. Newark, DE: MIDI Inc.

Stackebrandt, E. \& Goebel, B. M. (1994). Taxonomic note: a place for DNA-DNA reassociation and $16 \mathrm{~S}$ rRNA sequence analysis in the present species definition in bacteriology. Int J Syst Bacteriol 44, 846-849.

Staley, J. T. (1968). Prosthecomicrobium and Ancalomicrobium: new prosthecate freshwater bacteria. J Bacteriol 95, 1921-1942.

Tamaoka, J. \& Komagata, K. (1984). Determination of DNA base composition by reverse-phase high-performance liquid chromatography. FEMS Microbiol Lett 25, 125-128.

Tindall, B. J., Rosselló-Móra, R., Busse, H.-J., Ludwig, W. \& Kämpfer, P. (2010). Notes on the characterization of prokaryote strains for taxonomic purposes. Int J Syst Evol Microbiol 60, 249-266.

Uchino, Y., Hirata, A., Yokota, A. \& Sugiyama, J. (1998). Reclassification of marine Agrobacterium species: proposals of Stappia stellulata gen. nov., comb. nov., Stappia aggregata sp. nov., nom. rev., Ruegeria atlantica gen. nov., comb. nov., Ruegeria gelatinovora comb. nov., Ruegeria algicola comb. nov., and Ahrensia kieliense gen. nov., sp. nov., nom. rev. J Gen Appl Microbiol 44, 201-210.

Wayne, L. G., Brenner, D. J., Colwell, R. R., Grimont, P. A. D., Kandler, O., Krichevsky, M. I., Moore, L. H., Moore, W. E. C., Murray, R. G. E. \& other authors (1987). International Committee on Systematic Bacteriology. Report of the ad hoc committee on reconciliation of approaches to bacterial systematics. Int J Syst Bacteriol 37, 463-464.

Yi, H. \& Chun, J. (2006). Thalassobius aestuarii sp. nov., isolated from tidal flat sediment. J Microbiol 44, 171-176.

Yoon, J.-H., Kim, H., Kim, S.-B., Kim, H.-J., Kim, W. Y., Lee, S. T., Goodfellow, M. \& Park, Y.-H. (1996). Identification of Saccharomonospora strains by the use of genomic DNA fragments and rRNA gene probes. Int J Syst Bacteriol 46, 502-505.

Yoon, J.-H., Lee, S. T. \& Park, Y.-H. (1998). Inter- and intraspecific phylogenetic analysis of the genus Nocardioides and related taxa based on 16S rDNA sequences. Int J Syst Bacteriol 48, 187-194.

Yoon, J.-H., Kim, I.-G., Shin, D.-Y., Kang, K. H. \& Park, Y.-H. (2003). Microbulbifer salipaludis sp. nov., a moderate halophile isolated from a Korean salt marsh. Int J Syst Evol Microbiol 53, 53-57. 